Универзитет уметности у Београду, Факултет драмских уметности, Београд

DOI 10.5937/kultura2066170G

УДК 316.775/.776:7.097(497.11)

оригиналан научни рад

\title{
ОДГПОБАЛНОГКА TEЛEBИЗНJCKOM
}

\section{PИЈАЛИTИЈУУ СРБИЈИ}

Сажетак: Глобална превирања у свету се одражавају на сваку наиију понаособ и различите сегменте друштва, а изузетак није ни ријалити програм. Светске вође и политичари, као и комуникаиија и међуљудски односи великог броја људи у свету који су ьима у мањој или већој мери потчињени, може се посматрати као огромно ријалити подручје. То није онај класични ријалити програм ограничен у четири зида, али је упркос својој ширини нераскидиво повезан са телевизијом и мас-медијима. Ријалити програми у Србији су после „Великог Брата” у приличној мери еволуирали и попримили форме које излазе из оквира ријалитија, усвајајући широк спектар углавном негативних утииаја из различитих сфера друштва.

Кључне речи: ријалити програм, глобализачија, телевизија, масмедији, нуклеарни рат, медијски рат, рат информачија

Увод

Данашње прилике у свету можемо посматрати у контексту делимично изрежираних међуљудских односа који се одвијају у ријалити програму. Свакако, мора се узети у обзир чињеница да је то много веће ријалити подручје у којем се преплиће мноштво замршених путања унапред испланираних и спонтаних акција. У њему владају глобални закони, тачније закони јачег, пре свега у војном и економском погледу. Прилично је тешко у тако широком подручју без јасних граница - нарочито ако се узме у обзир да њихова крхкост утиче на очување националних држава и њиховог суверенитета, које угрожава глобализација као производ, између осталог, 
експанзивног капитализма - перцептивно објединити у великој мери раштркан ријалити садржај. Иако је лакше пратити ријалити на телевизији који омогућава анализу на знатно мањем узорку, то не умањује, нити доводи у питање постојање ријалитија у стварном животу, и то у глобалним оквирима. Тај ријалити простор на којем се одвија глобализација је огроман, али га је могуће у извесној мери смањити захваљујући сателитској комуникацији која омогућује истовремени пренос слика широм света. Иако је простор ријалити програма неупоредиво мањи и прецизно ограничен физичким границама, чак и у њему камера није у могућности да забележи баш сваки детаљ. Стога тзв. светски „глобални” ријалити, наспрам телевизијског ријалити програма, изгледа као бесконачно поље које се шири у недоглед, са лабавим или само делимично јасним границама, између којих се и слике губе и повремено појављују не дозвољавајући да се добије једна заједничка и обједињена слика. Једна од тих слика која се, попут ријалити програма, појављује у преносу уживо, јесте рат и његове пропратне појаве.

Без обзира на то што хладноратовске игре никада заправо нису ни престајале и постоји реална претња од нуклеарног рата са много моћнијим оружјем, у данашњем времену су можда најјаче оружје медији посредством којих се већ увелико води медијски рат. У том рату, који се из одређене перспективе може посматрати као тзв. глобални ријалити, много је већи број играча него у телевизијском ријалитију. Међутим, ови ријалити програми представљају убојито оружје у националним оквирима, и уједно су продужена рука глобалних сила и новог светског поретка који нарушавају границе и функционисање националних држава. Истовремено, у складу са циљевима светских сила које нарочито у мање развијеним земљама спроводе своју глобалну политику (и то често без поговора и уз свесрдну подршку политичара који су на власти), ријалити програм и власти у свакој таквој држави омогућује да у извесној мери лакше остварује и своје циљеве, преусмеравајући пажњу гледалаца (народа) са текућих и горућих политичких, економских, културних, па на крају крајева, и глобалних проблема, на привидну и деградирајућу забаву, а да при том та иста власт скида било какву одговорност са себе глумећи да (сходно свом популистичком залагању за слободу медија) нема никакве везе са тим. У тој ријалити џунгли успоставља се однос између владара и потчињених, између Великог Брата (Велике Браће) и учесника овог својеврсног експеримента. Тешко је утврдити ко је главни Велики Брат, и да ли он може бити само један, али је сигурно да постоје већа и мања Браћа у зависности од величине и снаге центара моћи из којих они управљају. 


\section{Глобализаччија - терор великих над малима}

Иако може утицати и позитивно на одређене аспекте друштва, глобализација доводи у питање суверенитет националних држава подривајући, пре свега, њихову економију. ${ }^{1}$ Економском глобализацијом се врши својеврстан терор над малим сувереним државама, које бивају принуђене да своју економију развијају према правилима великих играча на глобалном тржишту. ${ }^{2}$ Зигмунт Бауман (Zygmunt) сматра да је „'тржиште без граница' рецепт за неправду и, у крајњој линији, за нови светски непоредак у ком је политика та која постаје наставак рата другачијим средствима."” Доводећи их у економски зависан положај, велике силе не само да у великој мери креирају њихову економску политику већ посредно утичу и на формирање других сегмената друштва који произлазе или су на одређени начин повезани са економијом као полазном основом. Један од тих сегмената је и култура, а њено ширење се остварује путем културне глобализације која разбија културне баријере али истовремено и нарушава и обликује према својим узусима културни идентитет одређеног друштва. По Кејт Неш (Kate Naesh), глобални културни токови могу допринети нашем доживљају света као јединственог места: „Међутим, чак и без те глобалне свести, они утичу на то како у сопственој локалној средини живимо у односу на друге и у односу на представе других које до нас допиру преко масовних медија."4 Важан сегмент културне глобализације су масовне комуникације које омогућују везу са целим светом, а масовни медији као моћно оружје дају њеним креаторима велику предност у свеопштем медијском рату. Светске силе, које предводе САД, у процесу опште глобализације и потчињавања слабијих својим интересима користе сва средства која су им на располагању, а на

1 Јан Арт Шолте (Aart Scholte) мисли да „када је вођена на одређени начин, глобализација може да подстиче културалну разноврсност, препород и иновацију"; Šolte, J. А. (2009) Globalizacija: kritički uvod, Podgorica: CID, str. 56.

2 Пол Херст (Paul Hirst) и Грејем Томпсон (Grahame Thompson), пак, тврде да је „економија више интернационална него глобална, с обзиром на то да су националне државе и даље најмоћнији играчи на економском плану, како у смислу домаћих економија, тако и у односу на споразуме везане за управљање економским односима изван националних граница"; Hirst, Р. и Thompson, G. (1996) Globalization in Question: The International Economy and the Possibilities of Governance, Cambridge: Polity Press, p. 10.

3 Bauman, Z. (2010) Fluidni strah, Novi Sad: Mediterran Publishing, str. 114.

4 Neš, K. (2006) Savremena politička sociologija: globalizacija, politika $i$ moć, Beograd: JP Službeni glasnik, str. 65. Неш наводи и трећи аспект глобализације, поред економског и културног, а то је еколошки, тачније деградација животне средине. Исто, стр. 65-66. 
ГОРАН ГАВРИЋ

првом месту је то војна моћ помоћу које оне мењају и намећу своје законе. ${ }^{5}$ Шолте напомиње како вестернизација, модернизација и колонизација имају много дужу историју него савремена снажна глобализација: „Институције управљања, предузећа, мас-медији, академска друштва и удружења грађана у Западној Европи и Северној Америци важила су за најватреније промотере савремене глобализације.”б

Ове силе непрестано истичу тероризам као глобалну претњу, а заправо је то само изговор да под плаштом тобожње борбе за светску правду врше терор глобалног над слабијима и потлаченима. На крају крајева, они су ти који својим лошим поступцима распирују даље бујање тероризма. Бауман истиче да „имајући у виду природу модерног наоружања на располагању војскама, реаговања на таква терористичка дела морају изгледати чудно, трапаво и нејасно.” За разлику од оружаног потпиривања тероризма телевизија то ради много суптилније, али ништа мање ефикасно и на штету својих гледалаца (а грађана одређене државе) који бивају увучени у опасне медијске игре. Селективним преносима рата и ратних дешавања уживо - готово увек приказују оружане акције великих сила усмерене против правих и имагинарних терориста, које наводно имају за циљ борбу за светску правду - водеће медијске куће у свету гледаоцима сервирају исечене и вешто одабране делове тог глобалног ријалитија. ${ }^{8}$ Када је, пак, реч о акцијама које су претходиле овим потоњим, Франсоа Валтер (Francois Walter) пише о томе да умножавање неуморно приказиваних слика јесте начин да се разблажи и да се мало-помало обузда ужас: „Ако се изузму случајеви као што је трагедија од 11. септембра или обезбеђивање слика слабе резолуције које су снимиле камере за видео надзор, трагедије не остављају за собом

5 Бауман прави паралелу између оружја и безакоња: „Глобално безакоње и оружано насиље међусобно се потхрањују, међусобно се оснажују и поткрепљују; као што древна мудрост упозорава - in ter arma silent leges (када оружје говори, закони занеме)"; Bauman, Z. нав. дело, стр. 114.

6 Šolte, J. А. нав. дело, стр. 57.

7 Bauman, Z. нав. дело, стр. 126. Тако она захватају много већу област од оне која је погођена терористичким насиљем, и узрокују још бројније „колатералне жртве”, а тиме и више терора, раздора и дестабилизације него што би сами терористи могли да проузрокују - изазивајући тако још једно повећање количине наталожене огорчености, мржње и растућег беса, и још веће ширење редова потенцијалних следбеника терористичких идеја. Исто, стр. 126.

8 Долазак живог (live) „директног преноса”, који је изазван увођењем крајње брзине, претвара стару „телевизију” у „велику планетарну оптику.” Вирилио, П. (2000) Информатичка бомба, Нови Сад: Светови, стр. 17. 
директне преносе.”9 Жан Бодријар (Jean Baudrillard) сматра да је „насиље потенцијално у празнини екрана путем рупе коју овај отвара у менталном свету." 10 По њему чак медији свуда претходе терористичком насиљу, и то је заправо у складу са оном констатацијом да су масовни медији (међу њима и телевизија као један од водећих) средство манипулације и планиране или делимично планиране злоупотребе која може довести до катастрофалних последица. ${ }^{11}$

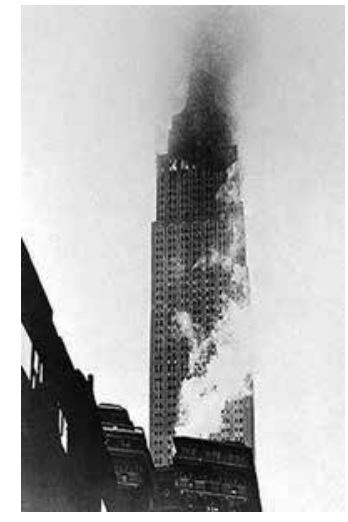

Слика 1 Емпајер стејт билдинг који гори након случајног удара авиона 1945. године

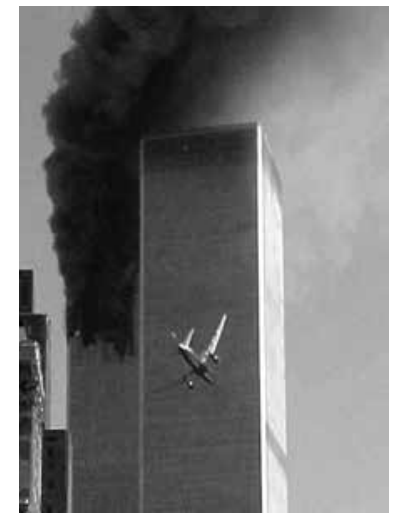

Слика 2 Авион којим управљају терористи се забија у Светски трговински центар 2001. године

Поред телевизије, ту је и интернет, који као производ Министарства одбране САД-а представља моћно оружје у рукама својих твораца за глобалну контролу других делова света. У одређеним случајевима интернет надомешћује недостатак медијске пажње на телевизији, када се, рецимо, терористи толико уживе у своје улоге да постају попут

9 Valter, F. (2012) Katastrofe: jedna kulturna istorija od XVI do XXI veka, Novi Sad: Akademska knjiga, str. 295-296. Пјер Бурдије (Pierre Bourdieu) је мишљења да „чак и најобичнији кратак преглед вести, па и сама чињеница да се о нечему извештава, да се нешто снима - to record, да се о нечему прави репортажа, подразумева увек и одређену социјалну конструкцију реалности која је у стању да изазове ефекте друштвене мобилизације (или демобилизације).” Burdije, P. (2000) Narcisovo ogledalo: rasprava o televizijskom novinarstvu, Beograd: Clio, str. 37.

10 Bodrijar, Ž. (1994) Prozirnost zla: ogled o krajnosnim fenomenima, Novi Sad: Svetovi, str. 71. О овоме он наставља: „До те мере да је боље не затећи се на јавном месту где оперише телевизија, имајући у виду велику вероватноћу једног насилног догађаја дозваног самим њеним присуством." Исто, стр. 71.

11 А Бурдије сматра да је „телевизија сигурно допринела, колико и мито, и деградацији цивилне врлине.” Burdije, Р. (1999) Signalna svetla: prilozi za otpor neoliberalnoj invaziji, Beograd: Zavod za udžbenike i nastavna sredstva, str. 10. 
ГОРАН ГАВРИЋ

медијских личности зависни од медија. Бауман тако наводи пример када „већина терористичких група, свесна да њихови спектакуларни подухвати могу бити пренебрегнути од стране извештача, жели да искористи прилике које пружају мреже 'информационих аутопутева' и редовно постављају вести о својим подухватима на интернету." 12 А Грант Вардлоу (Grant Wardlaw) је препознао како између медија и извршилаца спектакуларних терористичких инцидената постоји нека форма симбиотског односа, и да је један од најважнијих циљева терористичког напада задобијање публицитета из одређеног разлога: „У неким случајевима, публицитет је једини циљ. Претпостављени примарни циљ медија је информисање. Међутим, у пракси је важно макар забавити, шокирати, увеселити или на другачији начин утицати на емоције гледалаца. Ово је посебно тачно за медиј телевизије." 13 Све ове акције и реакције у глобалном превирању су, дакле, чврсто скопчане са мас-медијима, те из тог разлога никако не можемо занемарити њихову, у извесном смислу, ријалити димензију. Глобализација укључује веће и мање глобалне играче, али и оне учеснике који припадају антиглобалистичким покретима. Сви они су у једном огромном експерименталном простору звани ријалити. Разлика у односу на ријалити програм који обавља своју функцију у оквирима националне државе (посредно су ту ипак укључени и глобални утицаји), јесте та што овај тзв. глобални ријалити делује на много ширем пољу и при том често директне преносе замењује снимцима у пропагандне сврхе.

\section{Нуклеарни рат и медијска експлозија}

Када говоримо о опасностима које прете од нуклеарног рата, пажњу би заправо требало преусмерити на оно што претходи том потенцијалном завршном чину. То је неизвесност, страх и стрепња у непрестаном ишчекивању да ли ће и када

12 Bauman, Z. нав. дело, стр. 125. Бауман чак напомиње како „ретко прође дан, а да нека група не објави још један напад штампаним или видеосаопштењима." Исто, стр. 125.

13 Wardlaw, G. (1989) Political Terrorism: Theory, Tactics, and Counter-measures, Cambridge: Cambridge University Press, p. 20. Џонатан Р. Вајт (Јоnathan R. White) сматра да телевизија и други медији обликују начин на који ми видимо тероризам: „Ово ствара прилично контроверзе о улози медија у извештавању о тероризму, и често супротставља извештаче безбедносним снагама. Све стране покушавају да манипулишу медијима због његове велике моћи. Ово значи да постоји велико надметање да се прикаже тачка гледишта и оквир за вести, што доводи до оптужби за пристрасности са свих страна. Ово је нарочито тачно код телевизије, зато што је тероризам направљен за телевизијску драму.” White, J. R. (2014) Terrorism and Homeland Security, Wadsworth: Wadsworth Cengage Learning, p. 106. 
куцнути судњи час. Спенсер Верт (Spencer Weart) напомиње како је у прошлости најчешћи страх био онај од напада из ваздуха - не са атомским бомбама, ако су се уопште очекивале у далекој будућности, него са оружјем које је било већ при руци: „Није била нова идеја да би ужас модерног оружја могао да донесе доба мира, а изглед атомског оружја нарочито је инспирисао колико наде, толико и страха."14 У овоме велику, и можда кључну улогу имају медији (нарочито телевизија), који издвајањем и сецкањем већ окрњених и непотпуних слика обликују једну нову, у приличној мери од стварности удаљену слику. Бодријар мисли да смо захваљујући техничкој перформанси доспели до таквог степена реалности и објективности да се чак може говорити о вишку реалности: „Овај вишак нас још више плаши и збуњује него њен недостатак јер смо овај барем могли да надокнадимо утопијом и уобразиљом."15 Тај вишак је не тако ретко неухватљив за медије који су фрустрирани овом чињеницом, а када га је и могуће досегнути он на екрану бива тако упакован да гледаоци добијају једну нејасну представу о одређеним догађајима. Тако долазимо до ситуације да нама као гледаоцима, како пише Бодријар, највише недостаје управо мисао о довршењу реалности. ${ }^{16}$ Оно што је претходило глобалној експанзији медија, пре свега телевизије, и с тим у вези приказивања тема о нуклеарном рату и катастрофама, јесу сликарство и фотографија. ${ }^{17}$ Занимљиво је то да је Енди Ворхол (Andy Warhol) у једном интервјуу који је дао Микелеу Бонуомоу (Michele) 1985. године поново оживео слику катастрофе од 28. јула 1945. године, када је авион Америчког ратног ваздухопловства због густе магле ударио у 79. спрат

14 Weart, S. R. (2012) The Rise of Nuclear Fear, Cambridge, Massachusetts and London: Harvard University Press, p. 13.

15 Bodrijar, Ž. (1998) Savršen zločin, Beograd: Časopis Beogradski krug, str. 76.

16 Исто, стр. 77.

17 Под том пресијом и страхом од нуклеарног оружја и рата јавиле су се и специфичне манифестације у уметности. То је тзв. нуклеарна уметност која је настала недуго након бомбардовања Хирошиме и Нагасакија. Наиме, 1951. године италијански сликари Енрико Бај (Enrico) и Серђио Данђело (Sergio Dangelo) створили су покрет Arte Nucleare. Исте године је објављен „Мистични манифест” Салвадора Далија који представља мешавину католичког мистицизма и нуклеарних тема. Пре објављивања манифеста и недуго након завршетка Другог светског рата Дали је насликао Атомску идилу (1945) и Атомску Леду (1949). Из 1949. године је и слика француског уметника Бернарда Лоржуа (Bernard Lorjou) Атомско доба. У САД-у је 1955. године слику истог назива урадио сликар и фотограф Еуген фон Бруенханхајн (Eugene Von Bruenchenhein). Чувени британски скулптор Хенри Мур (Henry Moore) је 1967. године направио скулптуру под називом Нуклеарна енергија, хибридну нуклеарну печурку и људску, односно слоновску лобању садржане у једном. 
ГОРАН ГАВРИЋ

Емпајер стејт билдинга, тада највише зграде на свету. ${ }^{18}$ У овом случају стварна катастрофа је претходила уметниковој имагинацији катастрофе, а овом још нерођеном сликом Ворхол је на неки начин визионарски предвидео опет праву катастрофу (која се непрекидно у директном преносу и на снимцима вртела на Си-Ен-Ену) када су терористи авионима и бомбама готово 20 година касније, 11. септембра 2001. године, уништили Светски трговински центар у Њујорку који се налазио у близини поменуте зграде.

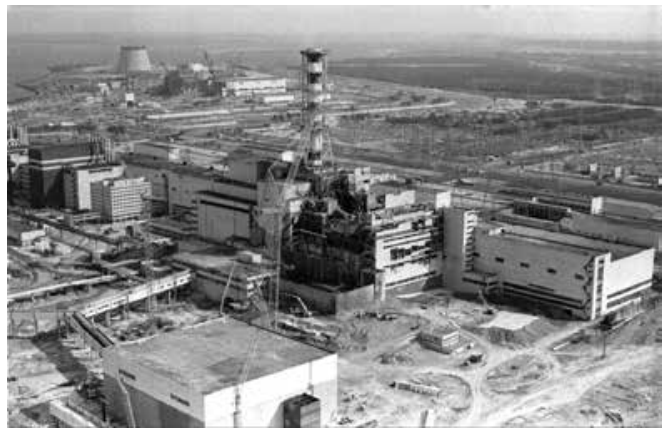

Слика 3 Нуклеарна катастрофа у

Чернобиљу из 1986. године

Гледаоци, односно директни учесници и жртве трагичних догађаја повезаних са нуклеарним ратом - када је нуклеарно оружје већ испробано на цивилним циљевима у 20. веку, и то пошто су Американци 1945. године бацили на Хирошиму и Нагасаки атомске бомбе - нису, нажалост, морали да својом имагинацијом попуњавају празнину како би створили реалну слику о овој страхоти. Прве манифестације тзв. нуклеарне уметности могле су се видети пре свега у фотографијама, и то почев од поменутих бачених атомских бомби, преко нуклеарних проба, па све до нуклеарних катастрофа у Чернобиљу 1986. и Фукушими 2011. године. Све ове догађаје је најбоље бележио фотоапарат, а фотографи су одабирали оне сегменте који су најупечатљивији и најбоље одражавају дату ситуацију. Помињући разне катастрофе, међу њима и Чернобил, Пол Вирилио (Paul) закључује да смо у тим временима одвраћања успели некако да се навикнемо на наш нови кошмар: „Захваљујући нарочито телевизији уживо, дуга агонија планете за нас је исто што и ток породичних

18 „Микеле Бонуомо: Да ли је ерупција Везува слика катастрофе за Вас? Енди Ворхол: Ох да! Мало је као атомска бомба. Да, мислим да тако функционише... Микеле Бонуомо: Да ли би Њујорк требало да има Везув? Енди Ворхол: Не, не могу да замислим тако нешто. Можда овде у Њујорку постоји само једна ствар која може да изгледа као Везув: Емпајер стејт билдинг. Ако би био запаљен." Wilson, R. (1991) American Sublime: The Genealogy of a Poetic Genre, Madison, Wisconsin: The University of Wisconsin Press, p. 41. 
серија." ${ }^{19}$ Наводећи пример фудбалске утакмице између Реал Мадрида и Наполија одигране у септембру 1987. године пред празним гледалиштем - при чему су хиљаде гледалаца опседали стадион али нису ушли унутра, а цели ток утакмице је преношен на телевизији - Бодријар истиче како забрана ове врсте савршено одсликава терористички хиперреализам нашега света, онај у коме се „стварни” догађај дешава у празнини, где му је одузет сваки контекст, и видљив је само издалека, телевизијски. ${ }^{20} \mathrm{y}$ случају апокалипсе, након нуклеарног рата, та празнина би у великој мери постала реалност, која се директно предочава тзв. ријалити играчима. Телевизија у тој ситуацији малтене не би морала ни да посредује у преношењу катастрофичних слика, катастрофа би се одвијала пред нашим очима као гледаоцима који су постали активни учесници у догађајима. Десила би се нека врста медијске експлозије која би практично уништила екран као виртуелни зид између два мање-више стварна света, и практично поништила нашу улогу пасивних гледалаца. На тај начин би се све оне исечене и монтиране слике распршиле, и у неком тренутку се претвориле у тзв. нуклеарну кишу која би творила стварност као једину могућу слику. Валтер наводи пример из романа Давида Елија (Ely) Tajм-aym (Time Out, 1968), где се Руси и Американци међусобно оптужују за нуклеарну несрећу која је уништила Велику Британију.

19 Вирилио, П. нав. дело, стр. 39.

20 Bodrijar, Ž. (1994) Prozirnost zla: ogled o krajnosnim fenomenima, Novi Sad: Svetovi, str. 75. Бодријар као да је визионарски предвидео ситуацију са којом се тренутно суочавамо, а то је пандемија новог корона вируса (Ковид 19). Наиме, на самом почетку пандемије фудбалске утакмице су се углавном играле без гледалаца, а један од ипак ређих случајева је била, рецимо, и утакмица Лиге шампиона између Ливерпула и Атлетико Мадрида, одиграна 11. марта 2020. године пред препуним стадионом Енфилд (из Мадрида као жаришта епидемије у Шпанији, у којој је већ тада било потврђених 2140 случајева заразе, допутовао је велики број навијача). А још фрапантнији пример је такође утакмица Лиге шампиона од 19. фебруара исте године, одиграна на стадиону Сан Сиро у Милану - између домаће Аталанте и Валенсије, када је око 40000 навијача стигло из Бергама неколико дана након што се вирус већ проширио у Кодоњу јужно од Милана; иначе, Бергамо је поред Милана касније постао најпогођенији град по броју смртних случајева у читавој Европи, па и свету, а на овој утакмици се заразила и трећина играча Валенсије, као и већи број шпанских навијача. Ако узмемо у обзир чињеницу да ce 2. априла у Шпанији број заражених попео на 110,238 а у Италији на 110,574 , можемо супротно Бодријару, закључити да се сада пред пуним гледалиштем одиграо тзв. капиталистички, односно финансијски тероризам због велике добити, а да су утакмице барем на празним стадионима могле да спрече исти. Касније су и саме утакмице забрањене због ризика за играче и чланове екипа, али се чини да је главни разлог ипак био несврховитост одигравања када нема никаквог прилива новца од улазница (у таквој ситуацији би била упитна и зарада од реклама и спонзора). 
ГОРАН ГАВРИЋ

Занимљивост приче је у томе што на сцену поставља историчара, који мора, не само да напише историју тог периода, него и да створи архиве, да обезбеди континуитет колекција новина и часописа, тако да у будућности не би могло ни да се посумња у постојање катастрофе. ${ }^{21}$

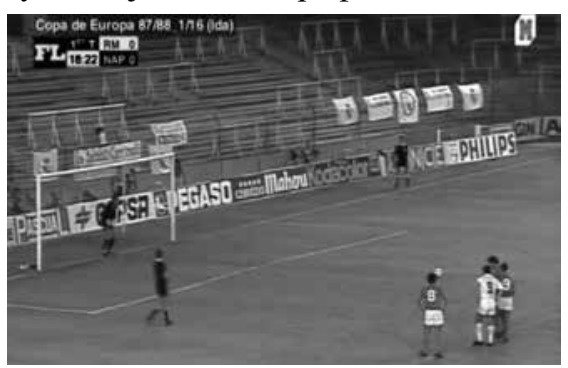

Слика 4 Фудбалска утакмица између Реал Мадрида и Наполија одиграна 1987. године пред празним гледалиштем

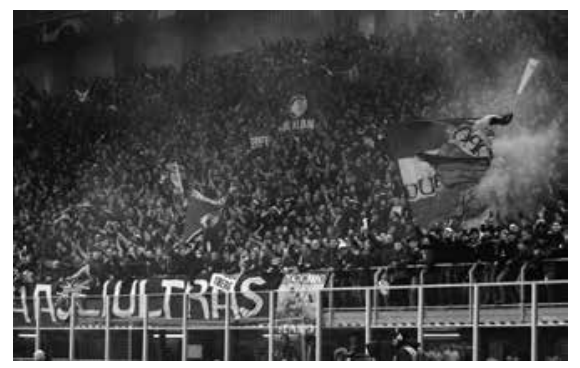

Слика 5 Препун стадион Сан Сиро на утакмици Лиге шампиона између Аталанте и Валенсије из 2020. године

Међутим, како пише Вирилио, на крају прошлог миленијума је атомску бомбу заменила авет информатичке бомбе која је кадра да раствори мир нација интерактивношћу информације. ${ }^{22}$ Напомињући да су рат маса и рат енергија (тоталитарни рат у којем је квантитативно још била доминантна маса и моћ атомске бомбе) завршени а да наступа pam информащија, он предвиђа даљи ток: „Глобалитарни рат сутрашњице биће рат у којем ће квалитет надвладати геофизичку и демографску величину, захваљујући информатичкој бомби." 23 Док у свету константно тиња стрепња од нуклеарног рата, на екрану нам се сервирају изнова и изнова садржаји на ову тему. ${ }^{24}$ Почев од 9. октобра 2006. године водеће

21 Valter, F. (2012) Katastrofe: jedna kulturna istorija od XVI do XXI veka, Novi Sad: Akademska knjiga, str. 204.

22 Вирилио, П. нав. дело, стр. 65.

23 Исто, стр. 138-139, 141.

24 Енди Ворхол је говорио да када видимо језиву слику изнова и изнова, то заиста нема никаквог ефекта. 


\section{ГОРАН ГАВРИЋ}

глобалне тв мреже, попут Си-ен-ена, понављале су нам нуклеарне пробе које је извела Северна Кореја, закључно са шестом и највећом изведеној 3. септембра 2017. године. Светске силе, на челу са САД, претиле су да, ако севернокорејски председник Ким Џонг Ун настави са развојем нуклеарног оружја, да ће његову земљу избрисати са лица земље. Али, наједанпут, као у ријалити програму, амерички председник Доналд Трамп (Donald Trump) почетком 2018. године омекшава свој став и пристаје да се у скорије време на неутралном терену састане са Уном. Међутим, ову сервирану ријалити причу је врло брзо распршила (и довела у питање одржавање састанка с циљем коначног постизања мира) изјава на телевизији Трамповог саветника за националну безбедност Џона Болтона (John Bolton) да би на Северну Кореју требало применити „либијски модел” денуклеаризације, али и стварна војна вежба коју су у међувремену заједнички извеле Јужна Кореја и САД. Ове ријалити игре не би требало да изненађују, с обзиром на то да је Трамп искусан ријалити играч, и да је и након ступања на дужност председника остао извршни продуцент ријалити шоу програма „Шегрт” (The Apprentice). ${ }^{25}$

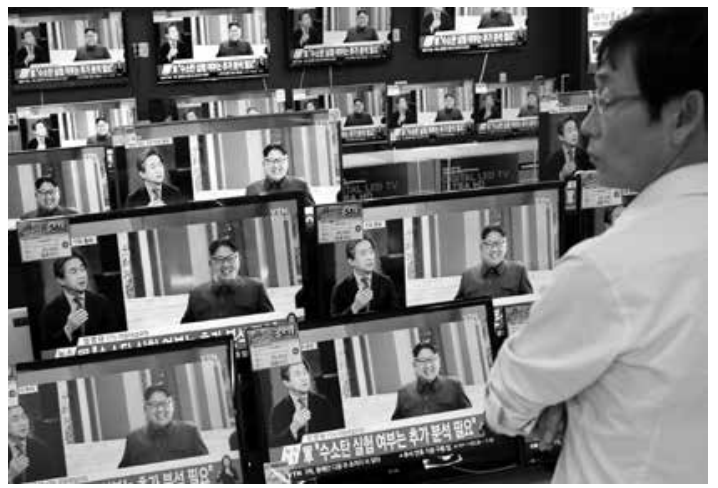

Слика 6 Продавац у Јужној Кореји у неверици гледа на екранима телевизора Ким Џонг Уна и вести о петој нуклеарној проби Северне Кореје, изведеној 9. септембра 2016. године

25 Састанак између Трампа и Уна је на крају ипак одржан у Сингапуру 12. јуна 2018. године (потписан је и документ о денуклеаризацији Корејског полуострва), али то можемо посматрати само као још један у низу ријалити потеза. Требало би напоменути да је Трамп активан и на друштвеним мрежама, конкретно Twitter-у, где често порукама послатим између и након важних састанака збуњује своје политичке противнике, али и сараднике. Након овог састанка уследиле су Трампове наизменичне похвале и претње, да би почетком децембра 2019. године Северна Кореја извела нове пробе. На то је Трамп реаговао написавши 8. децембра опет на Twitter-у како је Ким Џонг Ун у Сингапуру потписао чврст споразум о денуклеаризацији, и да ризикује да изгуби све ако настави да се непријатељски понаша. 
ГОРАН ГАВРИЋ

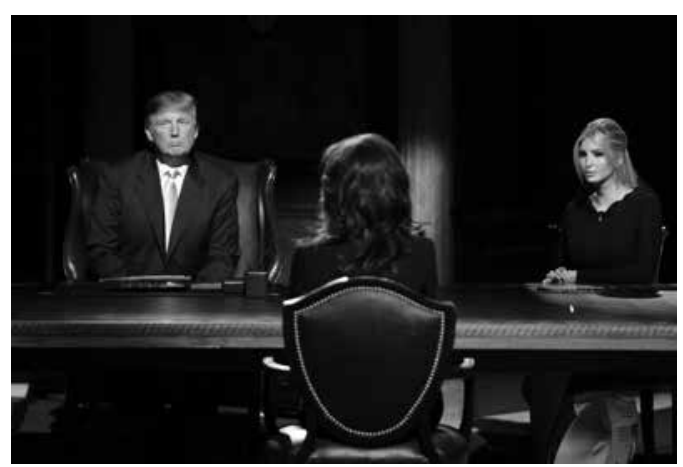

Слика 7 Доналд Трамп и његова ћерка Иванка Трамп разговарају са такмичарем „Шегрта”

\section{Владари (велика браћа) и потчињени (учесници)}

Иако ријалити шоу Велики Брат није више актуелан у свету (па самим тим ни у Србији) он је послужио као модел за многе потоње ријалитије, те је из тог разлога и термин „Велики Брат" најприкладнији када се прави паралела са светским владарима. ${ }^{26}$ Западна мисао је још од својих почетака у Грчкој, тежила да суштину човека и друштва дефинише политички („човек је политичка животиња”), у исто време видећи суштину политичког у подели друштва на надређене и подређене, на оне који знају и издају наредбе и на оне који не знају и који се тим наредбама покоравају. ${ }^{27}$ То је водило ка стварању друштва, али је зато даљи развој све више откривао последице само привидних слобода и у исто време ишао на руку глобалним владарима, као и владарима из сенке. Као и у ријалити програму, и у „глобалном” ријалитију владари (често су попут Великог Брата невидљиви) смишљају унапред већи број испланираних потеза које ће повући у тој игри, при том пуштајући учеснике до оне границе која им одговара да спонтано изводе своје улоге. Дакле, они настоје да колико год је то могуће држе све под својом контролом и имају власт над себи потчињенима, односно учесницима, што је у потпуној супротности са племенском друштвеном организацијом. Пјер Кластр (Pierre Clastres) тако истиче да

26 Крајем 1990-их година, „Велики Брат” је стигао на телевизијске екране, прво у Холандији и затим у другим земљама широм света. Технолошки, он је комбиновао систем камера дигиталне продукције које производе лако манипулирајуће слике употребом радио микрофона причвршћених за одећу такмичара, и користио је брзи софтвер високог капацитета који је постао индустријски стандард. Било је могуће веома брзо едитовати снимак за вечерњу компилацију програма који приказују најважније дневне догађаје у кући „Великог Брата”; Bignell, J. (2005) Big Brother: Reality TV in the Twenty-first Century, London: Palgrave Macmillan, p. 16.

27 Klastr, P. (2004) Društvo protiv Države - Vlast u primitivnom društvu: eseji iz političke antropologije, Porodična biblioteka, br. 2, drugo izdanje, str. 25. 
„поглавице код јужноамеричких Индијанаца немају никакву власт над племеном, да нема ни оних који издају наређења нити оних који се покоравају." ${ }^{28}$ И у „глобалном” и у ТВ ријалитију вође држе учеснике у зависном положају, и то почев од оних примарних па све до секундарних потреба. Тако је занимљиво да учесници у ријалити програмима на различите начине морају да отплате храну (кроз одрађивање и извођење различитих „улога”, а понекад и самим новцем који им је унапред дат) чију цену и услове куповине диктирају вође у односу на то како су извршени одређени задаци, а у „глобалном ријалитију” исто тако моћници мењају и одређују цене, и условљавају купце (који морају да се покажу на свом радном месту како би зарадили довољно новца за куповину) држећи монопол на прехрамбене производе. Џонатан Бигнел (Jonathan Bignell) напомиње како је структура награде и казне која је уобичајена за формате ријалитија, попут давања или ускраћивања хране (на шта су се учесници ријалити програма „Ја сам позната личност” и „Велики Брат” често жалили), и утврђивање очигледно насумичне рутине једења или спавања, усклађена са психолошком тортуром која има за циљ да ослаби жртву и произведе зависност од испитивача. ${ }^{29}$ У случају чланова племена појам ,елементарна економија" се односи на њихово одбијање сваког бесмисленог претеривања, њихову решеност да производну активност ускладе са задовољавањем својих потреба. Они у оквиру уобичајеног радног времена (без додатног рада) производе онолико колико им је потребно, па чак им остаје и вишак, а производна активност не служи задовољавању потреба других. ${ }^{30}$ Она тачка у којој се „глобални“ и телевизијски ријалити сусрећу чинећи границу између стварног и виртуелног крајње тананом, јесте видео-надзор код којег полиција и службе обезбеђења користе видео камере. Напомињући како је полицијском апарату својствена неодређена контрола, политичка власт над бескрајно сићушним, Мишел Фуко (Michel Foucault) пише следеће: „Да би се таква власт вршила, она мора да располаже инструментом сталног, свеобухватног, свеприсутног надзора који све чини видљивим,

28 У стварности, међутим, то што поглавица нема власт не чини га бескорисним. Напротив, друштво му додељује одређене задатке, тако да се на њега може гледати као на неку врсту неплаћеног јавног службеника. Исто, стр. 26.

29 Bignell, J. нав. дело, стр. 129.

30 Исто, стр. 8-9. Када су Индијанци открили производну надмоћ секире белог човека, почели су да је користе не зато да би производили више за исто време, већ исто колико и пре, само за десет пута краће време. Али, десило се супротно: заједно са металним секирама дошли су насиље и власт белих дошљака, што је направило праву пустош у примитивном индијанском свету. Исто, стр. 8. 
под условом да себе учини неприметним." ${ }^{31}$ И у једном и у другом ријалитију се успоставља дисциплина, о којој пише Фуко као умећу рангирања и техници трансформисања распореда, у којој су елементи међусобно заменљиви јер је сваки дефинисан местом које заузима у неком низу као и растојањем у односу на остале. ${ }^{32}$

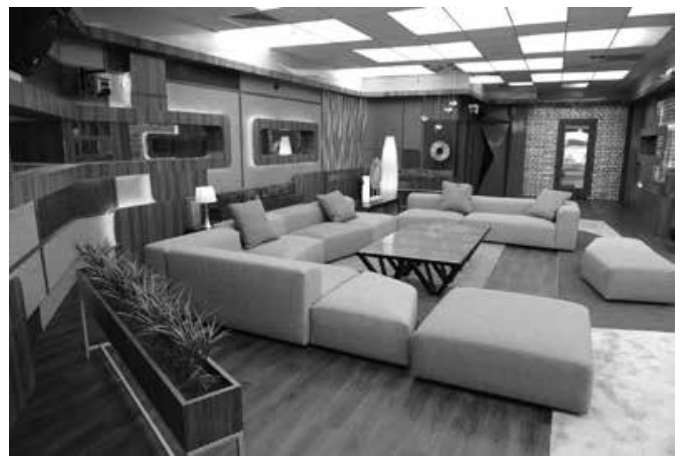

Слика 8 Модеран ентеријер у богатом колориту из пете сезоне „Великог Брата” (2015) у Србији

Сви ови ријалити играчи мењају своје позиције (чак и они невидљиви), које повремено бивају фиксиране да би водећи играчи прибавили бенефите на основу претходно креираних задатака. Ако изузмемо невидљиве играче (највероватније су то они изнад највећих) који у било ком погледу не могу доспети у видокруг гледалаца ријалитија, они највећи су мање више познати и известан број њихових акција можемо видети посредством телевизије. То су председници највећих војних светских сила, међу којима се истичу Доналд Трамп $^{33}$ и Владимир Путин (Влади́мир Пу́тин) на челу оних највећих, али се у тој испреплетеној комуникационој мрежи као занимљив феномен јавља присуство немачке канцеларке Ангеле Меркел као веома моћне и утицајне жене (многи је сматрају за водећу фигуру Европске уније). Ово је уједно и један од најинтригантнијих сегмената ријалитија,

31 Fuko, M. (1997) Nadzirati i kažnjavati, Sremski Karlovci - Novi Sad: Izdavačka knjižnica Zorana Stojanovića, str. 221.

32 Исто, стр. 194. Мерна јединица ту није територијална (јединица за доминацију), нити резиденцијална (јединица за пребивалиште), него ранг: место које се заузима у неком распореду, тачка укрштања вертикалне и хоризонталне линије, једно растојање у низу других која се сва сукцесивно могу прећи. Исто, стр. 194.

33 Миша Кавка (Misha) истиче како подстицај ријалити програма као што је „Шегрт” лежи у исплати која иде победнику на крају, годину дана плаћена позиција као шегрта Доналда Трампа у истом: „Ја називам овај нагласак на победи идеологијом пре него дефинисањем карактеристика игре, зато што изгледа природно и неспорно да циљ сваког учесника у овим програмима мора бити победа.” Kavka, M. (2012) Reality Tv, Edinburgh: Edinburgh University Press, p. 115. 
jep по први пут у глобалним политичким оквирима жена није сведена на стање објеката, или, боље, на симболичка средства мушке политике. Пратећи Левија-Строса, Бурдије управо разматра корениту дисиметрију између мушкарца, субјекта, и жене, објекта размене; између мушкарца, који је одговоран и господар производње и репродукције, и жене, преображене у производ овога рада. ${ }^{34}$ Пренасељеност и сиромаштво је такође проблем који владари најмоћнијих земаља константно пренебрегавају, издвајајући и изопштавајући учеснике из земаља трећег света у скрајнуте делове глобалног ријалити подручја, и дајући им минорне ријалити улоге. Ерих Фром (Erich Fromm) истиче како пренасељеност, тј. густина становништва у условима сиромаштва, изазива напетост и агресију: „Пренасељеност значи да је број људи у одређеном друштву надмашио економску основу која их снабдева адекватном храном, становањем и адекватним одмором." ${ }^{35}$ Иако и у ријалити програму често на једном месту имамо доста већи број учесника него што је потребно у нормалним условима живота, локална Велика Браћа нам шаљу поруку која се нимало не поклапа са реалним стањем ствари у глобалним, али и националним оквирима: Видите како ми решавамо проблеме пренасељености и сиромаитва, убаиујемо стално нове учеснике (иако се често врте једни исти) и награђујемо их храном и пићем у изобиљу (а на крају и новием) за юихов нерад (или у најмању руку упитан pad).

\section{Ријалити програм као огледало једног друштва}

Иако се на ријалити програм може применити добро позната латинска максима „хлеба и игара” (panem et circenses), његови негативни ефекти продиру знатно дубље и могу се одразити на различите сегменте друштва. Та опасност је постала реална са развојем самог друштва, али и са непредвидивим и неухватљивим кретањима глобализације чије последице се могу осетити на нивоу нација, па затим и на још мањем узорку ТВ ријалитија. ${ }^{36}$ Хијерархија, која је у „глобалном” ријалитију била вертикална (усмерена од глобалних ка националним вођама), у оквирима нације захваљујући ријалити програму постаје хоризонтална (вође се

34 Burdje, P. (2001) Vladavina muškaraca, Podgorica: CID, str. 64.

35 Fromm, E. (1989) Anatomija ljudske destruktivnosti, Prva knjiga, Zagreb: „Naprijed”, Nolit, str. 125.

36 На почетку је у Србији био „Велики Брат” као изум Џона де Мола (John) у својој изворној форми, али су се временом појавили „Фарма“, „Двор”, „Задруга”, „Парови” и др., који су потпуно мутирали и саобразили се друштвеном стању у држави и далекосежним циљевима одређених структура. 
ГОРАН ГАВРИЋ

утапају и прикривају своје улоге иза екранизованог апсурда, а сам ријалити постаје средство за остваривање одређених циљева). ${ }^{37}$ Телевизија представља једну посебно опасну форму симболичког насиља, а оно се и у ријалитију врши уз прећутно саучесништво оних који га трпе (гледалаца) и, исто тако, често и оних који га врше (Велика Браћа), и то у мери у којој су и једни и други несвесни да га чине или да га подносе (у сваком случају вође су много чешће свесне, јер су они ти који планирају унапред потезе). ${ }^{38}$ То се све одвија захваљујући, између осталог, и томе што за разлику од оне телевизије са самих почетака из 1940-их година, савремена телевизија следи логику забавног спектакла, показује више хај-тек сјаја, брже и блиставије едитовање, компјутерске симулације, и помоћу кабловске и сателитске телевизије, фантастичан низ свих замисливих врста емисија и жанрова. ${ }^{39}$ Учесници ријалитија се појављују на телевизији готово 24 сата дневно (чак и кад спавају), па не чуди да губе појам са реалношћу почевши да у појединим тренуцима умишљају како су главне звезде у земљи и шире, веће и од оних реалних (у суштини су ипак свесни да то није истина). Анет Хил (Annette Hill) описује верзију „Селебрити Великог Брата" из 2006. године у Британији, која је укључивала лажну познату личност убачену како би победила у програму, као пример продукције и пријема где се ради раме уз раме: „Продуценти додају нови образац у постојећи формат, а гледаоци га узимају за следећи ниво у ријалити игри. У смислу жанровског рада, када гледаоци сагледавају себе како гледају ријалити програм (ту сам и ја испред телевизора!), они рефлексно могу да одговоре на позитивне и негативне начине." ${ }^{40}$ Интересантно је да, када те тзв.

37 Како је глобалним силама и њиховим вођама у интересу да се мале нације уруше и још више ослабе, тако се њихови и циљеви малих вођа поклапају а циљ оправдава средства, ма каква она била (немогуће је чути ни реч критике амбасадора и других страних дипломата великих сила иако се нимало не либе тога у већини случајева - на рачун ТВ ријалитија и других штетних медијских садржаја усмерених ка даљем урушавању одређене мале и немоћне нације и друштва).

38 Burdije, P. (2000) Narcisovo ogledalo: rasprava o televizijskom novinarstvu, Beograd: Clio, str. 34.

39 Kellner, D. (2005) Media Culture and the Triumph of the Spectacle, in: The Spectacle of the Real: From Hollywood to Reality TV and Beyond, ed. King, G. (2005), Bristol, Portland: Intellect, p. 28.

40 Hill, A. (2007) Restyling Factual TV: Audiences and News, Documentary and Reality Genres, Abingdon, New York: Routledge, p. 106. Она сматра и да „идеја познатих личности, када се примењује на ријалити извођаче, јесте та да су они 'медијски врући' на начин који их омаловажава. Неки гледаоци се тако позивају на порнографску индустрију да би нагласили своју перцепцију ријалити извођача као оних који деградирају себе." Исто, стр. 201. 
ријалити звезде изађу повремено из свог ријалити уточишта у стварни свет, оне имају осећај да су и даље у ријалитију и уживају у пажњи коју им поклањају медији и обични људи на улици. Ервинг Гофман (Goffman) пише о томе да сама чињеница да је препознају странци на јавним местима може за особу представљати извор задовољства, као што наводи један млади глумац: „Кад сам постао познат и кад бих имао лош дан, практично бих рекао себи: 'Добро, мало ћу прошетати да ме људи препознају'."41 У ријалитију имамо један парадокс: фигуру коју учесник ријалитија живи пред очима колега са којима дели свакодневну рутину, али и гледалаца крај малих екрана, и њену угроженост виртуелним потребама које се у таквој, већ виртуелној и неприродној ситуацији, додатно усложњавају. ${ }^{42}$

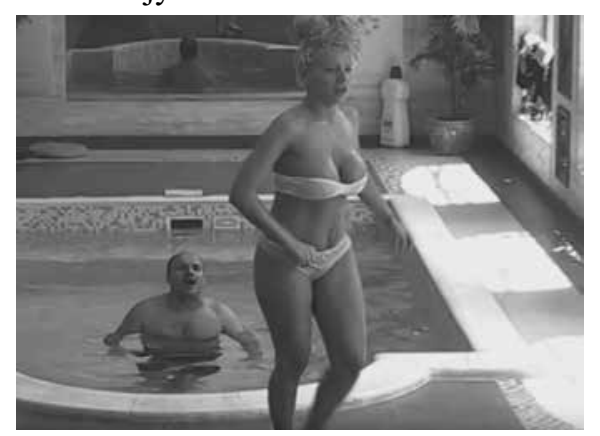

Слика 9 Змај од Шипова и порно глумица Невена

Хот на базену у четвртој сезони „Парова” (2016)

Једно од питања је и какве се поруке шаљу ријалити програмима по питању радне етике, када у њима учествују нерадници, људи без занимања, на ивици закона, а при том још добијају и новац за повећање гледаности. Зар не би било сврсисходније у држави у којој влада сиромаштво и велика незапосленост, где се чак и певачи (углавном новокомпоноване народне музике, који учествовањем у музичким такмичењима дају лош пример омладини да се на брз и лакши начин, а не учењем и радом, може обогатити и постати познат) пребацују у ријалитије - направити ријалити под називом „Радни логор”. Ако не би научио многобројне гледаоце радној етици и истинским људским вредностима, барем би, како пише Фуко, људско тело потпало под машинерију власти која би га истраживала, рашчлањивала и поново састављала, и то потпуно транспарентно. ${ }^{43}$ Ако изузмемо

41 Gofman, E. (2009) Stigma: zabeleške o ophođenju sa narušenim identitetom, Novi Sad: Mediterran Publishing, str. 80.

42 Исто, стр. 82.

43 Упоредити: Fuko, М. нав. дело, стр. 188. По Фукоу се тако „рађа 'политичка анатомија' која је истовремено и 'механизам власти'; њоме се 
ГОРАН ГАВРИЋ

психотерапеутско дејство, које му се у извесном смислу не може оспорити, ријалити програм, нарочито омладини (старији гледаоци су нешто мање угрожени, али нажалост остају неми), шаље нимало наивне поруке са потенцијално штетним дејством на његове конзументе. Да ли би требало да се запитамо у каквој то држави живимо, када су омладини узор и у ријалити програмима побеђују старлете, углавном ситни, али понекад и нешто крупнији криминалци који су међу најполуларнијим ријалити учесницима, а више него сумњиве „анимир даме” улазе повремено са задатком да анимирају одређене мушке учеснике како би се закомпликовали мушко-женски односи. Једна од главних тачака ових дама у ријалитију је стриптиз, боље рећи одређени елементи или стриптиз у покушају, чија је поента, како пише Ролан Барт (Roland Barthes) описујући париски стриптиз, да се жена десексуализује управо у тренутку када се разголићује: „Гледаоци постају воајери само док траје разголићавање; но ту се, као у свакој представи која обмањује, сценографија, прибор и стереотипи супротстављају почетној изазовности намере, а на крају је угуше у безначајности: зло се истиче да би се боље осујетило и егзорцирало." 44 Слике које се гледаоцима у овом случају предочавају су прилично мрачне и не уливају ни трунке оптимизма, али оно што се крије иза њих као својеврсног паравана је још мрачније и задире дубоко у национално и глобално подручје. Овде се Велика Браћа заправо служе симулацијом, да би, како пише Бодријар, решили проблем истине или реалности овог света: „Решили смо га техничким симулирањем и умножавањем слика у којима више нема шта да се види." 45

Ријалити програм тако користи и моћ телевизије да прикрије приказујући, и то приказујући сасвим друго од онога што би требало приказати, и то тако да изгледа као да чини оно

дефинише начин на који се може овладати телом других и утицати на њега, не само да би ти други чинили оно што се од њих жели, већ и да би се понашали онако како се од њих очекује, према утврђеним техникама и онолико брзо и ефикасно како се одреди. Тако дисциплина масовно производи потчињена и увежбана тела, 'послушна' тела. Она повећава телесне снаге (у смислу економске користи) и слаби исте снаге (у смислу политичке потчињености).” Исто, стр. 188.

44 Barthes, R. (2009) Mitologije, Zagreb: Naklada Pelago, str. 108.

45 Упоредити: Bodrijar, Ž. (1998) Savršen zločin, Beograd: Časopis Beogradski krug, str. 15. Византијски иконопоклоници били су истанчани људи који су сматрали да представљају Бога да би увећали његову славу, а заправо су, симулирајући Бога у сликама, прикривали проблем његове егзистенције. Иза сваке од тих слика, Бог је нестао. Није био мртав, већ је нестао. А то значи да се сам проблем више није постављао. Био је решен симулацијом. Исто, стр. 15. 
што би и требало да чини, то јест да информише. ${ }^{46}$ Простор и учесници ријалитија су осветљени јаким светлом како би били што видљивији, скоро ништа се не прикрива (да неки занимљив детаљ не би промакао гледаоцима), а ако нешто и не би требало да се види нека од бројних камера неће то ни снимити. ${ }^{47}$ Ово можемо упоредити са самицом, за коју Фуко напомиње како је изокренут њен принцип, односно од њене три функције - затворити, лишити светла и сакрити задржана је само прва, а одбачене су преостале две: „Пуно светло и поглед надзорника боље заробљавају него тама која je, коначно, штитила. Видљивост је клопка."48 Штетни утицаји културне глобализације могу се видети и на примеру пласирања културних садржаја неке нације другој, која под маском културне размене и развијања пријатељских односа заправо крије скривену намеру да се оправда нарушавање територијалног интегритета земље (у појединим случајевима и већ одузета територија) у којој се врши то пласирање. Ови утицаји су једним делом присутни и у ријалити програму, али они због националних оквира у којима он делује попримају површне и банализоване облике не-културе, кича и шунда. Они се преносе у ријалити и из других гледаних телевизијских емисија и шоуова, а њихово присуство је очигледно кроз понављање једне те исте новокомпоноване музике на тзв. ријалити журкама, истог профила учесника (старлете и естрадне звезде у покушају), раскошне и китњасте сценографије која даје лажну слику супротну оној реалној итд. Зигмунт Бауман истиче како култура не може живети у миру са управљањем: „Нарочито не са наметљивим и подмуклим управљањем које за циљ има извртање потребе културе за истраживањем и експериментисањем како би се култура уклопила у оквире рационалности по замисли управљача." ${ }^{49}$ На примеру ријалити програма се добро може

46 Упоредити: Burdije, Р. (2000), нав. дело, стр. 34.

47 Анет Хил истиче како је „Велики Брат” користио обичну локацију као позадину емоционалних тензија и психолошких махинација учесника који се такмиче да освоје много мање од милион: „Опет, величина новчане награде - само 70.000 фунти - указује на природу програма који се бави у ситним размерама, свакодневним активностима, а оне се потом увећавају у кући и на телевизији зато што постоји још мало тога на шта би се могло фокусирати (главна активност је спавање).” Hill, А. (2005) Reality Tv: Audiences and Popular Factual Television, London and New York: Routledge, p. 31.

48 Fuko, M. нав. дело, стр. 210. Фуко описује предности које осветљење доноси особи чија је улога да надзире: „На светлу које улази кроз прозор на спољашњем зиду, јасно се оцртавају, ономе ко посматра из куле, мале силуете затворене у ћелијама на ободу. Оне су попут низа кавеза, низа малих позорница на којима је само по један глумац, савршено индивидуализован и стално видљив." Исто, стр. 210.

49 Bauman, Z. (2010) Fluidni strah, Novi Sad: Mediterran Publishing, str. 70. 
уочити како свет игара престаје да буде непробојан, када га реални живот окружује и кад сваки гест за собом повлачи неизбежну последицу. Како пише Роже Кајоа (Roger Caillois), губитак правог идентитета представља казну за оног који не зна да се заустави само на игри, на жељи да изиграва неку другу личност (то је дословно алијенација), и овде игра штити од опасности - ТВ ријалитије можемо посматрати као уточишта у којима се учесници играју, али не могу при том избећи да се не тако ретко сусретну са стварношћу од које су покушали да побегну (огољавајући своје личности, све њихове особине, нарочито слабости и мане, постају лако уочљиве за гледаоце). ${ }^{50}$ Телевизија, с друге стране, као медиј пласирања ријалитија ослобађа Велику Браћу (али и гледаоце) физичког присуства, и на тај начин им омогућује да одређене своје улоге прикрију.

Ако узмемо у обзир чињеницу да су учесници ријалитија особе углавном без занимања, изграђене личности, са различитим психолошким и психичким проблемима, са врло слабом или никаквом радном етиком, окренути нелегалним пословима, ситном криминалу и проституцији, пропали и незајажљиви политичари ниског морала итд. - њихове улоге у самом ријалитију су крајње проблематичне и неутемељене. Дакле, они нису стручњаци ни у чему вредном пажње и поштовања, те тако ни не могу, како пише Гофман, заузети врло скромну улогу на улици, у продавници, или у свом дому, а у друштвеној сфери која обухвата изражавање њихове професионалне компетенције (у нашем случају би то био ријалити) строго водити рачуна да инсценирају ефектан наступ. ${ }^{51}$ Ријалити програми дезоријентисане и неактивне (по више аспеката, од незапослености па све до недостатка смисленог живота испуњеног различитим активностима) гледаоце у Србији даноноћно бомбардују и хране различитим садржајима који су испуњени скарадним и простачким понашањем и изражавањем, као и насиљем (у последње време су ријалитији толико „узнапредовали” да се дозвољава и физички контакт, где обезбеђење добија упутства да спречи да он само не поприми веће размере). Видели смо, поред свађа, туча и скарадног понашања, венчања, зачећа и трудноће (још да се види и тај завршни чин порођаја) које су само наивна и контрапродуктивна алузија на тобожњу борбу

50 Упоредити: Kajoa, R. (1979) Igre i ljudi: maska i zanos, Beograd: Nolit, str. $72,77$.

51 Упоредити: Gofman, Е. (2009) Stigma: zabeleške o ophođenju sa narušenim identitetom, Novi Sad: Mediterran Publishing, str. 46-47. Гофман тако напомиње да „стручњак током припрема пред наступ неће обраћати много пажње на укупан скуп различитих улога које изводи, већ само на ону из које се изводи његова професионална репутација.” Исто, стр. 47. 
државе за повећање наталитета. Практично нема много тога што још нисмо видели, још само да видимо, не дај Боже, неко убиство, или можда самоубиство. ${ }^{52}$ Али, то се највероватније неће догодити (на срећу, иако би ријалити у том случају далеко превазишао и своје већ снижене лимите). Много је извесније да ће се десити самоубиство нације, која сваким даном све више (нажалост, великим делом својом вољом) тоне у виртуелни муљ из кога је јако тешко извући се.

\section{ЛИТЕРАТУРА:}

Barthes, R. (2009) Mitologije, Zagreb: Naklada Pelago.

Bauman, Z. (2009) Fluidni život, Novi Sad: Mediterran Publishing.

Bignell, J. (2005) Big Brother: Reality TV in the Twenty-first Century, London: Palgrave Macmillan.

Bodrijar, Ž. (1994) Prozirnost zla: ogled o krajnosnim fenomenima, Novi Sad: Svetovi.

Bodrijar, Ž. (1998) Savršen zločin, Beograd: Časopis Beogradski krug.

Burdije, P. (1999) Signalna svetla: prilozi za otpor neoliberalnoj invaziji, Beograd: Zavod za udžbenike i nastavna sredstva.

Burdije, P. (2000) Narcisovo ogledalo: rasprava o televizijskom novinarstvu, Beograd: Clio.

Burdije, P. (2001) Vladavina muškaraca, Podgorica: CID.

Fromm, E. (1989) Anatomija ljudske destruktivnosti, Prva knjiga, Zagreb: „Naprijed”, Nolit.

Fuko, M. (1997) Nadzirati i kažnjavati, Sremski Karlovci - Novi Sad: Izdavačka knjižnica Zorana Stojanovića.

\footnotetext{
52 Епидемија корона вируса која је започела у Кини крајем децембра 2019. и затим се претворила у пандемију проширивши се већ у фебруару 2020. године и на остатак света, утицала је у одређеној мери и на ријалити програме. Међутим, чини се, барем за сада, да та промена није суштинске природе - гледаоци су сада исто у изолацији, али се концепт ријалитија и перцепција гледалаца у основи не разликују од пређашњег стања. Ова промена је, пре свега, тренутна, као што се и код свих осталих људи који воде нормалне животе по завршетку ове кризне ситуације највероватније неће, под утицајем исте, догодити неке круцијалне животне промене. Не могу да улазе нови учесници (постоји чак и ту понеки изузетак, када је нови такмичар наводно прошао кроз карантин), музичари, гости, родбина, што сада учеснике ријалити програма доводи у донекле сличну ситуацију у којој су биле њихове колеге из „Великог Брата”. Ипак, разлика је та што учесници данашњих ријалити програма нису препуштени сами себи у затвореном простору, него и даље све време комуницирају са водитељима (они су само у другом студију) у емисијама посредством тв екрана, а ту је и обезбеђење и екипа за техничку подршку (храна и друге потрепштине). Али, ипак треба сачекати неко време и након прикупљања свих релевантних чињеница размотрити прилике у ријалити програму, које ће се евентуално изменити услед свега поменутог.
} 


\section{ГОРАН ГАВРИЋ}

Gofman, E. (2000) Kako se predstavljamo u svakodnevnom životu, Beograd: Geopoetika.

Gofman, E. (2009) Stigma: zabeleške o ophođenju sa narušenim identitetom, Novi Sad: Mediterran Publishing.

Hill, A. (2005) Reality Tv: Audiences and Popular Factual Television, London and New York: Routledge.

Hill, A. (2007) Restyling Factual TV: Audiences and News, Documentary and Reality Genres, Abingdon, New York: Routledge.

Hirst, Р. и Thompson, G. (1996) Globalization in Question: The International Economy and the Possibilities of Governance, Cambridge: Polity Press.

Kajoa, R. (1979) Igre i ljudi: maska i zanos, Beograd: Nolit.

Kavka, M. (2012) Reality Tv, Edinburgh: Edinburgh University Press.

Kellner, D. Media Culture and the Triumph of the Spectacle, in: The Spectacle of the Real: From Hollywood to Reality TV and Beyond, ed. King, G. (2005), Bristol, Portland: Intellect, pp. 23-37.

King, G. (2005) The Spectacle of the Real: From Hollywood to Reality TV and Beyond, Bristol, Portland: Intellect.

Klastr, P. (2004) Društvo protiv Države - Vlast u primitivnom društvu: eseji iz političke antropologije, Porodična biblioteka, br. 2, drugo izdanje.

Neš, K. (2006) Savremena politička sociologija: globalizacija, politika i moć, Beograd: JP Službeni glasnik.

Šolte, J. A. (2009) Globalizacija: kritički uvod, Podgorica: CID.

Valter, F. (2012) Katastrofe: jedna kulturna istorija od XVI do XXI veka, Novi Sad: Akademska knjiga.

Вирилио, П. (2000) Информатичка бомба, Нови Сад: Светови.

Wardlaw, G. (1989) Political Terrorism: Theory, Tactics, and Counter-measures, Cambridge: Cambridge University Press.

Weart, S. R. (2012) The Rise of Nuclear Fear, Cambridge, Massachusetts and London: Harvard University Press.

White, J. R. (2014) Terrorism and Homeland Security, Wadsworth: Wadsworth Cengage Learning.

Wilson, R. (1991) American Sublime: The Genealogy of a Poetic Genre, Madison, Wisconsin: The University of Wisconsin Press. 
ГОРАН ГАВРИЋ

\author{
Goran Gavrić \\ University of Arts in Belgrade, Faculty of Dramatic Arts, Belgrade
}

FROM GLOBAL TO REALITY TV SHOWS IN SERBIA

\begin{abstract}
In Serbia, reality television programmes came to life with "Big Brother", an invention of Dutchman "John" de Mol, initiated as a kind of experiment that was inspired by contemporary artists' research into how police and security services use video cameras. This resulted in creation of a space in which everyone comes to be seen and to see others. In the meantime, many circumstances have changed, both globally and in Serbia, so after "Big Brother", the reality television programmes in our country have evolved considerably and have taken forms that fall outside the reality, adopting a wide range of mostly negative influences from different spheres of society. To what extent has television, with its displaying of various forms of non-culture and kitsch through television broadcasts and shows, exerted its influence that such a stunning transformation of this form of reality TV has occurred? And does it mean that an unfortunate bare picture of the overall social situation in the country and the far-reaching goals of certain structures underlie these negative enough influences? By bringing small states into an economically dependent position, the great powers not only considerably shape their economic policy but also indirectly influence the formation of other segments of society that emerge or that are in some way connected with their emerging economies. One of these segments is culture, and its spread is achieved through cultural globalization which breaks down cultural barriers. However, at the same time, it distorts and shapes the cultural identity of a particular society according to its own needs. Although the wellknown Latin maxim of "bread and games" (panem et circenses) can be applied to reality television programmes, their negative effects extend much deeper and can affect different segments of society. This danger has become real with the development of the society itself, but also with the unpredictable and elusive movements of globalization, the consequences of which can be felt at national level, even on a smaller sample of reality television programmes. The hierarchy, which was vertical in the "global" reality (directed by the global towards the national leaders), becomes horizontal within a nation, thanks to the reality television programmes (leaders are drowning and concealing their roles behind the screened absurdity, and the reality itself becomes a means to certain ends). If we exclude psychotherapeutic effect, which in some sense cannot be denied, the reality TV sends a not at all naïve message, with potentially harmful effects on its viewers.
\end{abstract}

Key words: reality television programme, globalization, television, mass media, nuclear war, media war, information war 